SPECIAL ARTICLE / ARTIGO ESPECIAL

\title{
The impact of the COVID-19 pandemic on the
} provision of dental procedures performed by the Brazilian Unified Health System: a syndemic perspective

\section{O impacto da pandemia de Covid-19 na oferta de procedimentos odontológicos realizados pelo Sistema Único de Saúde: uma perspectiva sindêmica}

\author{
Amanda Ramos da Cunhal (D), Sofia Rafaela Maito Velasco" (D), \\ Fernando Neves Hugo' (D), José Leopoldo Ferreira Antunes" (iD
}

\begin{abstract}
Objectives: This study investigated the impact of the COVID-19 pandemic on the provision of dental care procedures performed by the Brazilian Unified Health System (SUS) nationally and by regions. Considering that the most underprivileged population disproportionately suffers with the reduction in dental care provision, the study hypothesis suggests the presence of a syndemic nature. Methodology: The SUS Outpatient Information System (SIA-SUS) was assessed to gather data on dental care activities and procedures performed between April and July 2018, 2019, and 2020 by dentists registered in the SUS. The 30 most frequent activities and procedures performed by dentists were selected and classified into three categories (urgent dental care, nonemergency dental care, and case-dependent urgency procedures), based on the guidance for dental care during the pandemic published by the American Dental Association. Results: Results demonstrated a reduction in the provision of dental care of all categories during the pandemic. Urgency dental consultations and procedures in primary and specialized dental care services decreased by 42.5 and $44.1 \%$, respectively, between 2020 and 2019. Non-urgent procedures decreased by $92.3 \%$. Although decreases in dental care activities and procedures were reported in all Brazilian regions, the largest relative decreases in urgent procedures - that should have been maintained during the pandemic - occurred in the North and Northeast regions, which are the poorest regions of the country. Conclusions: These results suggest that the COVID-19 pandemic has a syndemic behavior. Further investigation into the pandemic-syndemic impacts on oral disease burden is necessary.
\end{abstract}

Keywords: Coronavirus infections. Pandemics. Dental care. Oral health. Healthcare disparities.

'Faculty of Dentistry, Universidade Federal do Rio Grande do Sul - Porto Alegre (RS), Brazil.

"Public Health School, Universidade de São Paulo - São Paulo (SP), Brazil.

Corresponding author: Sofia Rafaela Maito Velasco. Public Health School, Universidade de São Paulo. Avenida Doutor Arnaldo, 715, Cerqueira César, CEP: 01246-904, São Paulo, SP, Brazil. E-mail: sofiamaito@hotmail.com

Conflict of interests: nothing to declare - Financial support: Coordination for the Improvement of Higher Education (CAPES, Brazil) — Finance Code 001 . 
RESUMO: Objetivo: O presente estudo investigou o impacto da pandemia de Covid-19 na oferta de atendimento odontológico pelo Sistema Único de Saúde (SUS) no Brasil. Considerando que a população de menor nível socioeconômico sofre desproporcionalmente com a redução da oferta de atendimento odontológico, a hipótese do artigo sugere a presença de caráter sindêmico nessa situação. Métodos: O Sistema de Informação Ambulatorial do SUS (SIA-SUS) foi utilizado para coletar os dados das atividades e procedimentos odontológicos realizados entre abril e julho de 2018, 2019 e 2020 por dentistas cadastrados no SUS. Os 30 procedimentos mais frequentes realizados por dentistas foram selecionados e classificados em três categorias (atendimento odontológico de urgência, atendimento odontológico não emergencial e atendimento de urgência dependente de casos), com base nas orientações para atendimento odontológico durante a pandemia em curso, publicadas pela Associação Odontológica Americana. Resultados: Houve uma redução na oferta de atendimento odontológico em todas as categorias durante a pandemia. As consultas e procedimentos odontológicos de urgência em serviços de atenção básica e especializada diminuíram 42,5 e 44,1\%, respectivamente, entre 2020 e 2019. Os procedimentos não urgentes diminuíram $92,3 \%$. Embora as reduções nas atividades e procedimentos odontológicos tenham ocorrido em todas as regiões brasileiras, as maiores quedas relativas aos procedimentos de urgência — que deveriam ter sido mantidas durante a pandemia de covid-19 - ocorreram nas regiões Norte e Nordeste, que são as mais pobres do país. Conclusões: Os resultados sugerem que a pandemia covid-19 possui um comportamento sindêmico. Uma investigação mais aprofundada sobre os impactos da pandemia-sindemia na carga de doenças bucais é necessária.

Palavras-chave: Infecções por coronavírus. Pandemias. Assistência odontológica. Saúde bucal. Disparidades em assistência à saúde.

\section{INTRODUCTION}

The COVID-19 pandemic has been impacting healthcare services and systems worldwide $^{1}$. The need to guarantee and prioritize the provision of assistance for the diseased and the concern with contagion outlined a reaction scenario reflected in all healthcare areas. Dental care and oral medicine face a dilemma: considering the high risk of infection in the dental environment ${ }^{2}$ - that adds up to the baseline risk of the pandemic - and the elective character of most procedures, should dental care be postponed?

Oral diseases are a critical public health issue, affecting about half of the global population ${ }^{3}$. In August 2020, the World Health Organization (WHO) published a set of guidelines entitled Considerations for the provision of essential oral health services in the context of COVID-19, in which it advises that routine non-urgent oral healthcare and aesthetic treatments should be delayed until there has been sufficient reduction in COVID-19 transmission rates or according to official recommendations. Nonetheless, urgent or emergency dental care should be provided ${ }^{4}$. According to the American Dental Association (ADA), dental emergencies are potentially life-threatening situations, and urgent dental care is focused on the relief of severe pain or risk of infection and on alleviating the burden on hospital emergency departments; both require immediate care 5 .

The Brazilian Unified Health System (Sistema Único de Saúde - SUS) has a national oral health program that provides dental care including a wide range of dental procedures, 
health promotion and prevention as well as dental clinical care in primary and specialized dental services that are spread throughout the country. To the best of the authors' knowledge, there is no comprehensive, national analysis of the extent at which the COVID-19 pandemic affected the provision of dental care. Analyzing the SUS register constitutes a unique opportunity to provide detailed information on the amount of disruption in dental care delivery systems caused by the current pandemic.

Health authorities have characterized the outbreak of COVID-19 as a syndemic ${ }^{6}$. This concept recognizes this disease and its consequences as a social and biologically broader process, which results in the mutual worsening of individuals' health and life conditions $^{7}$. SARS-CoV-2 infection is more severe in patients with comorbidities; at the same time, COVID-19 makes preexisting conditions worse. In this context, social inequalities overturn the balance, as the most economically vulnerable individuals tend to have more comorbidities - mainly uncontrolled ones -, while they are less likely to keep themselves safe from the infection and have access to health care. This cycle feeds back and portrays the syndemic nature of this pandemic ${ }^{6,8}$. This study assumes that the lack of access to dental services is one of the drivers of the syndemic - along with drivers such as aging, unemployment, lack of social support, and other factors at the contextual level. The study hypothesis is that there are inequalities related to access, meaning that the negative impact of the pandemic on the organization of public dental services - i.e., the reduction in dental care provision - has been more severe in the most impoverished regions of Brazil.

The first death by COVID-19 in Brazil occurred on March 17, 2020. Since then, the country has accumulated more than 230 thousand deaths and more than 9 million confirmed cases (data referring to February 2021) ${ }^{9}$. This study aims to investigate the impact of the pandemic - considering its peak months -in the provision of dental care by SUS, nationally and by regions, identifying the nature of dental care delivery (urgent or elective). Furthermore, it aims to identify whether this negative impact on the organization of public dental care provision has been more accentuated in the poorest regions of the country, indicating that differences suggest the syndemic nature of the COVID-19 pandemic.

\section{METHODS}

The SUS Outpatient Information System (Sistema de Informação Ambulatorial-SIA-SUS) was the source of data on delivered dental care procedures. Data on all the dental procedures performed in April, May, June, and July 2018, 2019, and 2020 by dentists registered in the SUS were collected under six categories that include all general dentists and dentists with specialization in dental public health. PubData collection (by month and according to five Brazilian regions - South, Southeast, Midwest, Northeast, and North) was carried out using Tabwin, a proprietary tabulation tool of SUS that is of public access and provides information without any individual identification. 
North and Northeast are the poorest regions of the country in terms of Gross Domestic Product (GDP) per capita (BRL 17,213.30 and 12,954.80, respectively) and Human Development Index (HDI) (0.667 and 0.663) - for the Southeast, these metrics are 34,789.78 and 0.766 , respectively. While in the Southeast, South, and Midwest regions less than $3.5 \%$ of the population lives in extreme poverty, this percentage in the North and Northeast is 11.4 and $13.7 \%$, respectively ${ }^{10,11}$. Regarding oral health, the North region has the highest average of the sum of the number of decayed, missing due to caries, and filled teeth in the permanent teeth (DFTM) at 12 years of age (3.16), and the highest average of missing teeth among older adults (27.4) - with the Northeast region occupying the second-worst position in both metrics ${ }^{12}$.

Subsequently, the 30 most frequent dental procedures delivered in the country between April and July 2019 were selected. These procedures were classified into three categories, based on an adaptation of the ADA guidance for dental care during the pandemic, as follows: urgent dental care, nonemergency dental care, and case-dependent urgency procedures -i.e., those in which the classification as urgent depends on the severity of each case. This third category was developed in order to consider the relative nature of some procedures, which may or may not represent an urgency situation. The procedures are presented in Table 1.

\section{RESULTS}

From April to July 2019, general dentists and public health dentists delivered and promoted 34,300,275 dental procedures and activities on SUS - considering the 30 most frequent types of these activities. In the same period of 2020 , that number was $3,967,176$, representing a reduction of $88.4 \%$ in dental productivity during the first four months of the COVID-19 pandemic in Brazil.

There was a significant decrease in productivity in the three analyzed categories. Non-urgent procedures and activities decreased by $92.3 \%$, when comparing 2020 with 2019. In this category, all dental public health procedures showed more than $90 \%$ of decrease. Procedures that are strictly of preventive nature, such as dental sealants (-97.3\%) and dental plaque disclosing (-95.4\%), also significantly decreased. Case-dependent urgency procedures decreased by $89 \%$. This category includes some of the most common dental procedures, such as restoration of posterior permanent teeth and extraction of permanent teeth - with reductions of 95.6 and $87.9 \%$, respectively. Urgent dental care showed the lowest decrease, but this was still relevant $(-72 \%)$. Urgency dental consultations in primary and specialized dental care services decreased by 42.5 and $44.1 \%$, respectively (Table 1 ).

All regions of Brazil showed significant reductions in the number of dental procedures and activities delivered in the initial months of the COVID-19 pandemic when compared with the same months of 2019. The Southeast was the only region where urgent dental procedures surpassed non-urgent and case-dependent urgency procedures. The largest relative decreases in urgent procedures were verified in the North and Northeast regions (Figure 1). 
Table 1. Number of dental procedures performed in April, May, June, and July, 2018-2020, and percent of change, comparing 2020 to 2019. Brazil and its regions.

\section{Procedures}

2018

2019

2020

$\%$ Change

Nonemergency dental care

\begin{tabular}{|c|c|c|c|c|}
\hline Primary dental care consultation & $2,942,075$ & $3,254,469$ & 352,409 & -89.2 \\
\hline Initial dental consultation & $2,612,736$ & $2,189,679$ & 478,357 & -78.2 \\
\hline $\begin{array}{l}\text { Consultation in specialized dental care } \\
\text { service }\end{array}$ & 574,221 & 603,498 & 191,703 & -68.2 \\
\hline Dental scaling, planing, and polishing & $3,250,198$ & $2,753,890$ & 103,217 & -96.3 \\
\hline Topical fluoride application & $1,110,441$ & $1,366,662$ & 56,334 & -95.9 \\
\hline Root scaling and planing & $1,305,423$ & $1,151,853$ & 57,771 & -95.0 \\
\hline Dental cleaning & $1,524,532$ & $1,146,313$ & 35,511 & -96.9 \\
\hline Dental plaque disclosing & $1,368,581$ & 671,635 & 30,706 & -95.4 \\
\hline Dental sealant application & 430,077 & 368,947 & 9,817 & -97.3 \\
\hline Biofilm removal & 261,268 & 275,806 & 37,060 & -86.6 \\
\hline Group action of supervised toothbrushing & $5,129,600$ & $3,892,881$ & 177,454 & -95.4 \\
\hline Group action of fluoride mouth rinse & $1,597,684$ & $1,400,434$ & 24,101 & -98.3 \\
\hline Oral epidemiological examination & $1,618,369$ & 961,358 & 18,395 & -98.1 \\
\hline Group action of fluoride gel application & $1,392,083$ & 648,701 & 13,562 & -97.9 \\
\hline Group dental education in primary care & 601,058 & 446,025 & 34,916 & -92.2 \\
\hline Total & $25,718,346$ & $21,132,151$ & $1,621,313$ & -92.3 \\
\hline
\end{tabular}

Urgent dental care

\begin{tabular}{l|c|c|c|c}
\hline Urgent dental consultation in primary care & $1,656,796$ & 949,764 & 546,584 & -42.5 \\
\hline Urgent dental consultation in specialized care & 314,784 & 300,929 & 168,344 & -44.1 \\
\hline Temporary dental restoration & 866,737 & $1,407,238$ & 253,917 & -82.0 \\
\hline Dental abscess drainage & 37,737 & 835,348 & 13,082 & -98.4 \\
\hline Removal of sutures & 410,618 & 623,552 & 216,677 & -65.3 \\
\hline Dental pulp capping & 551,208 & 397,020 & 44,376 & -88.8 \\
\hline Access to and medication of the dental pulp & 644,646 & 396,735 & 135,677 & -65.8 \\
\hline Temporary endodontic treatment & 323,262 & 306,733 & 111,237 & -63.7 \\
\hline Dental pulpotomy & 495,402 & 182,559 & 19,657 & -89.2 \\
\hline Total & $5,301,190$ & $5,399,878$ & $1,509,551$ & -72.0 \\
\hline & & & & Continue...
\end{tabular}


Table 1. Continuation.

\begin{tabular}{l|c|c|c|c|}
$\begin{array}{l}\text { Procedures } \\
\text { Case-dependent urgency }\end{array}$ & 2018 & 2019 & 2020 & $\%$ Change \\
\hline Posterior permanent tooth restoration & $3,115,526$ & $3,009,722$ & 133,876 & -95.6 \\
\hline Permanent tooth extraction & $2,211,527$ & $2,172,611$ & 263,305 & -87.9 \\
\hline Anterior permanent tooth restoration & $1,064,177$ & 909,225 & 77,667 & -91.5 \\
\hline Primary tooth extraction & 314,586 & 674,285 & 43,436 & -93.6 \\
\hline Primary tooth restoration & 633,067 & 556,244 & 244,183 & -56.1 \\
\hline Interproximal or periapical radiograph & 432,662 & 446,159 & 73,845 & -83.4 \\
\hline Total & $7,771,545$ & $7,768,246$ & 836,312 & -89.2 \\
\hline
\end{tabular}
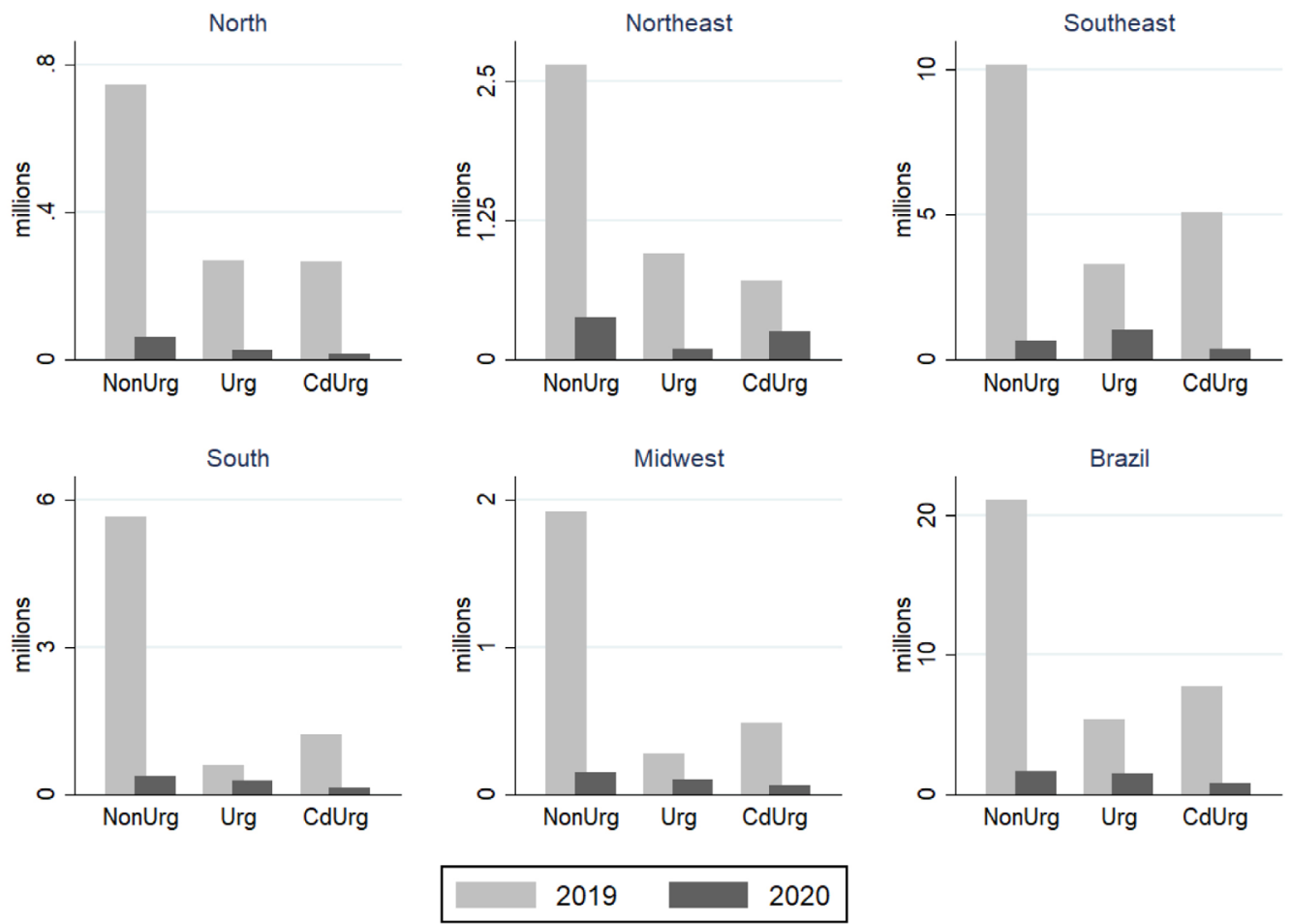

NonUrg: non-urgent procedures; Urg: urgent procedures; CdUrg: case-dependent urgency procedures.

Figure 1. Number of dental procedures in April, May, June, and July, 2019-2020. Brazil and its regions. 


\section{DISCUSSION}

This study investigated the provision of dental care in the public health system of Brazil, SUS, during the first four months of the COVID-19 pandemic. The decrease in oral health prevention and promotion initiatives is recommended and follows the social distancing guidance. The American Dental Association and the World Health Organization advised postponing activities, such as dental cleaning and aesthetic dental procedures, during the pandemic and keeping urgent dental care functioning ${ }^{5}$. Our findings showed that the urgent dental care provision dramatically reduced in Brazil, demonstrating a general lack of preparedness of the Brazilian health system. Certainly, abscesses that lead to severe dental pain and swelling cases did not simply vanish because of the pandemic. Possible reasons may include lack of government communication to the population about the services available during the pandemic, and the inability of public services to maintain the provision of essential care. The fear of exposure to contamination may also have distanced patients with dental needs from healthcare services ${ }^{13}$. In addition to pain, suffering, and the risk of worsening infections that unattended patients may have experienced, the repressed demand is likely to overburden the dental care services network in the post-pandemic period.

With the need to postpone elective procedures due to the high risks of contamination of the dental environment and even the lack of personal protective equipment ${ }^{14}$, the COVID-19 pandemic sparked the discussion about what are dental urgencies and emergencies. Fortunately, unlike definitions that do not reach consensus in the literature (such as "essential oral health care" and "basic oral health care"), dental urgencies and emergencies seem to be classifications with universally-adopted concepts. During the pandemic, articles and official documents reinforced and even refined these classifications. Benzian et al. ${ }^{15}$ merged some definitions to simplify the concept of urgent oral health care: it "describes interventions for oral diseases and conditions that are serious in terms of bleeding, infection, swelling, or pain or that otherwise impact with significant consequences if left unattended, therefore requiring treatment or referral without delay." However, the guidance that dental professionals should only attend dental urgencies and emergencies during the pandemic is not a consensus in the literature, although these are recommendations of the most influential institutions in dentistry ${ }^{15}$.

Urgent dental consultations did not decrease in the same proportion as urgency procedures. A possible explanation would be that dentists managed dental pain using a pharmacological approach to avoid procedures and their aerosols. Nonetheless, the effectiveness of pharmacological management of dental pain in the long-term needs to be analyzed. An urgent dental consultation is registered whenever a dentist attends a patient who has a dental emergency, even if there is no clinical procedure (e.g., in the case of a consultation that only resulted in a prescription). If a procedure is performed, the dentist reports both activities: the procedure and the consultation. Furthermore, wealthier regions (South and Southeast) presented less dramatic reductions in urgent dental care, reinforcing inequalities in the provision of dental care that are known to exist in the country. Many studies reported 
expressive regional inequalities in dental care in Brazil ${ }^{16,17}$. The North and Northeast regions have a lower provision of dental care and reduced access to health services in general ${ }^{17}$. The results of the present study suggest that the pandemic period is exacerbating these regional inequities.

To the best of the authors' knowledge, this study is the first to assess the syndemic nature of the COVID-19 pandemic in relation to its deleterious impact on the provision of oral health care. According to epidemiological data, the infection and mortality by SARS-CoV-2 have been unequally spreading, with more vulnerable groups being disproportionately affected because of inequalities in noncommunicable diseases and the social determinants of health that intensify existing health conditions ${ }^{6,8}$. The existence of significant barriers to the access to healthcare services for the most disadvantaged populations is an effect of the pandemic that can exacerbate existing inequities. The present study indicates that, in Brazil, this undesirable pattern reached oral health services.

Recently, two wide-ranging publications highlighted the need to rethink the provision of oral health care, concluding that what dentistry has been delivering worldwide is insufficient to deal with the enormous burden of oral diseases ${ }^{3,18}$. The pandemic impact on dental care must be pondered, as the findings reported in this study for Brazil may be taking place in other contexts as well. In other words, similarly unprepared dental care delivery systems that are not able to provide timely and required care globally. This is aggravated by the fact that most health systems often neglect oral health ${ }^{18}$.

The COVID-19 pandemic has been negatively affecting dental care provision in Brazil. Analyses that indicate significant decreases in the provision of biopsies of oral soft tissues and prostheses performed by SUS have already been published ${ }^{19,20}$ and are complemented by results of clinical dental care reported in the present study. The rate of performing soft tissue biopsies of the mouth provided by SUS - which is considered a nonelective procedure - decreased by almost 70\% in Brazil, when comparing May with March 2019 with the same period of $2020^{20}$. A study that assessed the impact of the pandemic on pediatric dental treatments performed by SUS found that the productivity related to dental procedures of May 2020 was more than $90 \%$ lower than that of May 2019²1. The pandemic seems to have negatively impacted even the care of head and neck cancer: data from referral services in Brazil and other countries indicate significant reductions in surgeries and hospital visits of patients undergoing treatment $\mathrm{t}^{22,23}$.

The most vulnerable populations are the most dependent on SUS. This study showed a reduction in the supply of dental care of all types during the pandemic period - preventive, restorative, and urgent. Along with the economic recession scenario that the pandemic has exacerbated and with the history of repressed dental demands in the country, mainly concentrated in the most vulnerable populations, the post-pandemic period reserves critical challenges for the SUS oral healthcare network. This study reported the pandemic impacts on the field of public oral health, highlighting that the reorganization of these services will require extensive resources and efforts. Future studies evaluating the impacts of the pandemic on oral disease burden are of strategic relevance to support the formulation 
of innovative care models that are responsive to the population's oral health needs and to address the social determinants of oral health.

\section{REFERENCES}

1. World Health Organization. Rapid assessment of service delivery for noncommunicable diseases (NCDs) during the COVID-19 pandemic [Internet]. [cited on June 20, 2020]. Available from: https://www. who.int/docs/default-source/ncds/ncd-covid-19/ for-web---rapid-assessment---30-june-2020-(cleared). pdf?sfvrsn $=6296324 \mathrm{c} \_208$ download $=$ true

2. Volgenant C, Persoon IF, de Ruijter R, de Soet J. Infection control in dental health care during and after the SARS-CoV-2 outbreak. Oral Dis 2020. https: / / doi. org/10.1111/odi.13408

3. Peres MA, Macpherson LMD, Weyant RJ, Daly B, Venturelli R, Mathur MR, et al. Oral diseases: a global public health challenge. Lancet 2019; 394(10194): 24960. https:// doi.org/10.1016/S0140-6736(19)31146-8

4. World Health Organization. Considerations for the provision of essential oral health services in the context of COVID-19 [Internet]. World Health Organization; 2020 [cited on June 20, 2020]. Available from: https://www.who.int/publications/i/item/ who-2019-nCoV-oral-health-2020.1

5. American Dental Association. What Constitutes a Dental Emergency? [Internet]. American Dental Association [cited on June 20, 2020]. Available from: https: / / success.ada.org/ /media/CPS/Files/ Open\%20Files/ADA_COVID19_Dental_Emergency_ DDS.pdf?_ga $=2.253879752 .110187285 .1584496315$ 1622146531.1565271894

6. Horton R. Offline: COVID-19 is not a pandemic. Lancet 2020; 396(10255): 874. https:// doi.org/10.1016/ s0140-6736(20)32000-6

7. Singer M, Bulled N, Ostrach B, Mendenhall E. Syndemics and the biosocial conception of health. Lancet 2017; 389(10072): 941-50. https://doi. org/10.1016/S0140-6736(17)30003-X

8. Bambra C, Riordan R, Ford J, Matthews F. The COVID19 pandemic and health inequalities. J Epidemiol Community Health 2020; 74: 964-8. http:// doi. org/10.1136/jech-2020-214401

9. Coronavírus Brasil [Internet]. 2020 [cited on Feb. 8, 2021]. Available from: https:// covid.saude.gov.br/

10. United Nations Development Program (PNUD-Brazil). Atlas of Human Development in Brazil [Internet]. [cited on Nov. 18, 2020]. Available from: http:/ / www. atlasbrasil.org.br/

11. Instituto Brasileiro de Geografia e Estatística. Portal [Internet]. [cited on Nov. 25, 2020]. Available from: https: / / www.ibge.gov.br/

12. Brasil. Ministério da Saúde. Coordenação Nacional de Saúde Bucal. Condições de saúde bucal da população brasileira. Resultados principais [Internet]. Brasília: Ministério da Saúde; 2010 [cited on Nov. 25, 2020]. Available from: https://bvsms.saude.gov.br/bvs/ publicacoes/SBBrasil_2010.pdf

13. Sardella A, Varoni E, Carrassi A, Pispero A, Lombardi N, Lodi G. Who's afraid of the big bad wolf? The experience of an Oral Medicine Unit in the time of Corona-Virus. Oral Dis 2020. https: / / doi.org/10.1111/ odi.13461

14. Ranney ML, Griffeth V,Jha AK. Critical supply shortages - the need for ventilators and personal protective equipment during the Covid-19 pandemic. N Eng J Med 2020; 382(18): e41. https: / / doi.org/10.1056/ NEJMp2006141

15. Benzian H, Beltrán-Aguilar E, Marthur MR, Niederman R. Pandemic Considerations on Essential Oral Health Care. J Dent Res 2020; 100(3): 221-5. https: / doi. org $/ 10.1177 / 0022034520979830$

16. Neves M, Giordani JMA, Neves Hugo F. Primary dental healthcare in Brazil: the work process of oral health teams. Ciênc Saúde Coletiva 2019; 24(5): 1809-20. https://doi. org/10.1590/1413-81232018245.08892017

17. Casotti E, Contarato PC, Fonseca ABM, Borges PKO, Baldani MH. Atenção em Saúde Bucal no Brasil: uma análise a partir da Avaliação Externa do PMAQ-AB. Saúde Debate 2014; 38(N. Esp.): 140-57. https: / / doi. org/10.5935/0103-1104.2014S011

18. Watt RG, Daly B, Allison P, Macpherson LMD, Venturelli R, Listl S, et al. Ending the neglect of global oral health: time for radical action. Lancet 2019; 394(10194): 26172. https: / / doi.org/10.1016/S0140-6736(19)31133-X

19. Chisini LA, Sartori L, Costa FDS, Salvi LC, Demarco FF. COVID-19 pandemic impact on prosthetic treatments in the Brazilian Public Health System. Oral Dis 2020. https:/ / doi.org/10.1111/odi.13668 
20. Cunha AR, Antunes JLF, Martins MD, Petti S, Hugo FN. The impact of the COVID-19 pandemic on oral biopsies in the Brazilian National Health System. Oral Dis 2020. https: / / doi.org/10.1111/odi.13620

21. Chisini LA, Costa FDS, Demarco GT, Silveira ER, Demarco FF. COVID-19 pandemic impact on paediatric dentistry treatments in the Brazilian Public Health System. Int J Paediatr Dent 2021; 31(1): 31-4. https: / / doi.org/10.1111/ipd.12741

22. Alves FA, Saunders D, Sandhu S, Xu Y, Mendonça NF, Treister NS. Implication of COVID-19 in oral oncology practices in Brazil, Canada, and the United States. Oral Dis 2020. https: / doi.org/10.1111/odi.13493

23. Morrison DR, Gentile C, McCammon S, Buczek E. Head and neck oncologic surgery in the COVID19 pandemic: Our experience in a deep south tertiary care center. Head Neck 2020; 42(7): 1471-6. https: / / doi.org/10.1002/hed. 26262
Received on: $01 / 18 / 2021$

Revised on: 02/10/2021

Approved on: 02/19/2021

Authors' contributions: Cunha, AR: substantial contributions to conception and design, acquisition of data, analysis, and interpretation of data; draft of the article. Velasco, SRM: substantial contributions to conception and design, analysis, and interpretation of data; draft of the article. Hugo, FN: substantial contributions to conception and design, analysis, and interpretation of data; critically review of the article for important intellectual content. Antunes, JLF: substantial contributions to conception and design, analysis, and interpretation of data; critically review of the article for important intellectual content. All authors gave their final approval and agreed to be accountable for all aspects of the study. 